\title{
ALLOTYPES OF THE FOURTH COMPONENT OF COMPLEMENT IN KOREAN
}

\author{
Kyoung Sook PARK, ${ }^{1, *}$ Soo Youn ChOI, ${ }^{1}$ Myoung Hee PARK, ${ }^{2}$ \\ and Katsushi ToKunaGA ${ }^{3}$ \\ ${ }^{1}$ Department of Biology, Sung Shin Women's University, Seoul, Korea \\ ${ }^{2}$ Seoul National University College of Medicine, Seoul, Korea \\ ${ }^{3}$ Department of Research, Japanese Red Cross Central Blood Center, \\ Shibuya-ku, Tokyo 150, Japan
}

\begin{abstract}
Summary The analysis of genetic polymorphism in $\mathrm{C} 4$ was performed on EDTA-plasma from 169 healthy unrelated Koreans. Plasma samples were subjected to high-voltage agarose gel electrophoresis followed by immunofixation. C4B allotypes were further detected by a hemolytic overlay method. The allele frequencies of $\mathrm{C} 4 \mathrm{~A}$ and $\mathrm{C} 4 \mathrm{~B}$ were as follows; for $\mathrm{C} 4 \mathrm{~A}, \mathrm{C} 4 \mathrm{~A}^{*} 3=0.6099, \mathrm{C} 4 \mathrm{~A}^{*} 4=0.1702, \mathrm{C} 4 \mathrm{~A}^{*} \mathrm{Q} 0=0.1525, \mathrm{C} 4 \mathrm{~A}^{* 2}=$ 0.0461 , and $C 4 A^{*} R=0.0213$; for $C 4 B, C 4 B^{*} 1=0.6406, C 4 B^{*} 2=0.2740$, $\mathrm{C} 4 \mathrm{~B}^{*} 5=0.0569, \quad \mathrm{C} 4 \mathrm{~B}^{*} \mathrm{Q} 0=0.0178$, and $\mathrm{C} 4 \mathrm{~B}^{*} \mathrm{R}=0.0107 . \quad \mathrm{C} 4 \mathrm{~A}^{*} 3$ and $C 4 B^{* 1}$ were among the most common alleles at each locus. $C 4 A * 6$ was not detected in this study, but this allele is relatively common in both Caucasoid and Negroid populations. C4B*5 is a common allele in Asian, which is rare in Caucasoids and Negroids. C4B*5 appeared to be a characteristic allele of Oriental. In the $\mathrm{C} 4 \mathrm{~A}$ locus, five individuals with duplicated allotypes (three C4A $3,3+2$, one C4A 4,3+2, and one $\mathrm{C} 4 \mathrm{~A} 3,3+3)$ were observed, and in the $\mathrm{C} 4 \mathrm{~B}$ locus, one individual with duplicated allotype (C4B 1,1+1) was detected.
\end{abstract}

\section{INTRODUCTION}

The human complement component 4 (C4), is a component protein of $\mathrm{C} 3$ convertase in the classical activation pathway. It is composed of three disulfide-linked chains, $\alpha$ chain of molecular weight (Mr) 93,000, $\beta$ chain of $\mathrm{Mr} 78,000$, and $\gamma$ chain of $\mathrm{Mr} 20,000$, but is synthesized as a single polypeptide of about $\mathrm{Mr} 209,000$ containing 1,722-1,744 amino acids before being secreted (Schreiber and Müller-Eberhard, 1974; Tack et al., 1981; Porter, 1985; Yu, 1991). The concentration of C4 is $27-32.03 \mathrm{mg} / \mathrm{dl}$ in the serum of normal human (Chiarelli et al., 1988; Vergani,

Received August 25, 1992; Revised November 9, 1992.

*To whom correspondence should be addressed. 
1987).

The $\mathrm{C} 4$ protein is encoded by two genetic loci, $\mathrm{C} 4 \mathrm{~A}$ and $\mathrm{C} 4 \mathrm{~B}$, located between HLA-B and HLA-D in the major histocompatibility complex on the short arm of chromosome 6 (6p21.3) (Carroll et al., 1984; Dunham et al., 1987; Spence et al., 1989). The two genes are arranged in tandem that are about $10 \mathrm{~kb}$ apart from each other and approximately $30 \mathrm{~kb}$ apart from the $\mathrm{C} 2$ and $\mathrm{BF}$ genes (Carroll et al., 1984) and less than $2 \mathrm{~kb}$ apart from the $2 \mathrm{l}-\mathrm{OH}$ genes (Carroll et al., 1985).

The various allotypes of $\mathrm{C} 4$ genes show genetic polymorphism in structural, functional, serological, and hemolytic characteristics. Human C4 structural polymorphism was first identified by Rosenfeld et al. (1969) using agarose gel electrophoresis. And then after a family study, it showed that the polymorphism of $\mathrm{C} 4$ was controlled by two closely linked genetic loci. The results were confirmed by improved electrophoresis after desialisation of plasma (O'Neill et al., 1978; Awdeh and Alper, 1980). So far, at least 13 alleles of C4A and 16 alleles of C4B including a null allele at each locus have been identified among various populations (Mauff et al., 1990). C4A and $\mathrm{C} 4 \mathrm{~B}$ genes have been found to be duplicated and to be transmitted to offspring in several different haplotypes (Raum et al., 1984; Giles et al., 1987). C4A and C4B can be distinguished by specific antisera, anti-Rogers and anti-Chido respectively, and reversed correlation have been found infrequently (Giles, 1990). Mauff et al. (1984) showed that the C4B protein has a higher hemolytic activity than $\mathrm{C} 4 \mathrm{~A}$. These functional and structural differences have been determined by a sequence of four amino acids in the $\mathrm{C} 4 \mathrm{~d}$ region ( $\mathrm{Yu}$ et al., 1988).

The present study was performed to investigate the genetic polymorphism of $\mathrm{C} 4 \mathrm{~A}$ and $\mathrm{C} 4 \mathrm{~B}$ in Korean and the results were discussed in comparison with that of other populations.

\section{SUBJECTS AND METHODS}

The EDTA-plasma was collected from a total of 259 healthy Koreans including 109 unrelated subjects and 30 families each with 3 children living in Seoul. None of the couples of the 30 families were consanguineous, and therefore, they were considered 60 unrelated subjects making the total number 169 . The allotyping of C4 was performed on samples pretreated with carboxypeptidase B and neuraminidase using a high-voltage agarose gel electrophoresis followed by immunofixation. $\mathrm{C} 4 \mathrm{~B}$ allotypes were further detected by a hemolytic overlay method (Mauff et al., 1983).

The nomenclature used for the $\mathrm{C} 4$ allotypes was according to Mauff et al. (1990).

\section{RESULTS}

The genetic polymorphism of C4 was observed in 169 unrelated healthy Koreans. Figure la demonstrates the $\mathrm{C} 4$ immunofixation and Fig. 1 b demonstrates 


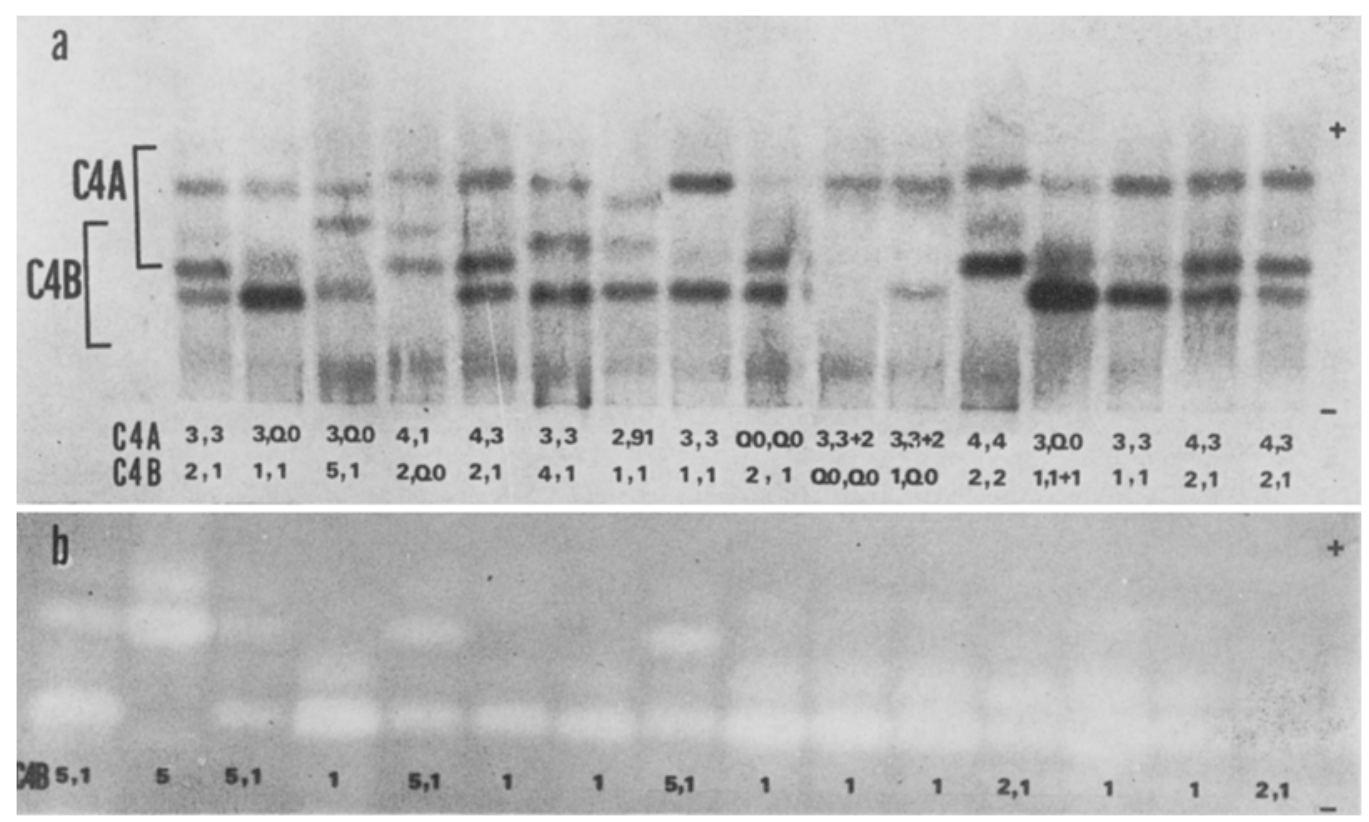

Fig. 1, a, C4A and C4B allotypes detected by immunofixation. b, C4B allotypes detected by hemolytic assay.

hemolytic patterns of the various phenotypes observed in this study. The hemolytic activities of $\mathrm{C} 4 \mathrm{~B}$ variants were higher than the $\mathrm{C} 4 \mathrm{~A}$. The distribution of $\mathrm{C} 4 \mathrm{~A}$ and $C 4 B$ allotypes and allele frequencies is shown in Table 1. Four common $\left(A^{*} Q 0, A^{*} 2, A^{*} 3\right.$, and $\left.A^{* 4}\right)$ and two rare $\left(A^{*} 1\right.$ and $\left.A^{*} 91\right)$ alleles and two duplicated haplotypes $\left(A^{*} 3+3\right.$ and $\left.A^{*} 3+2\right)$ at the $C 4 A$ locus and four common $\left(B^{*} Q 0\right.$, $B^{*} 1, B^{*} 2$, and $\left.B^{*} 5\right)$ and two rare $\left(B^{*} 4\right.$ and $\left.B^{*} 13\right)$ alleles and one duplicated haplotype $\left(\mathrm{B}^{*} 1+1\right)$ at the $\mathrm{C} 4 \mathrm{~B}$ locus were identified. Three individuals with duplicated C4A $3,3+2(1.8 \%)$, one with C4A $4,3+2(0.6 \%)$, one $\mathrm{C} 4 \mathrm{~A}$ with $3,3+3(0.6 \%)$, and one $\mathrm{C} 4 \mathrm{~B} 1,1+1(0.6 \%)$ were found. $\mathrm{C} 4$ phenotypes of individuals with $\mathrm{du}$ plicated haplotype were as follows; two individuals with $\mathrm{C} 4 \mathrm{~A} 3,3+2 \mathrm{C} 4 \mathrm{~B} 1,1$, one with C4A 3,3+2 C4B 1,Q0, one with C4A 3,3+3 C4B 1, Q0, one with C4A 4,3+2 C4B 2,Q0, and one with C4A 3,Q0 C4B 1,1+1.

\section{DISCUSSION}

Eight alleles $\left(\mathrm{CA}^{*} \mathrm{Q} 0, * 1, * 2, * 3, * 4, * 91, * 3+2, * 3+3\right)$ at the $\mathrm{C} 4 \mathrm{~A}$ locus and seven alleles (C4B*Q0,*1,*2,*4,*5,*13,*1+1) at the $\mathrm{C} 4 \mathrm{~B}$ locus were observed in Koreans. The $\mathrm{C} 4$ shows a high degree of polymorphism and several alleles show remarkable differences in various populations. In Table 2, the reported C4 alleie frequencies in various ethnic groups are presented. The distribution 
Table 1. C4 phenotype and allele frequencies in Korean.

\begin{tabular}{|c|c|c|c|c|}
\hline \multicolumn{2}{|c|}{ Phenotype } & \multirow{2}{*}{$\frac{\mathrm{n}}{53}$} & \multirow{2}{*}{$\frac{\%}{31.4}$} & \multirow{2}{*}{$\begin{array}{c}\text { Allele frequencies }(\%) \\
A^{*} 3=0.6099\end{array}$} \\
\hline $\mathrm{C} 4 \mathrm{~A}$ & 2 & & & \\
\hline & $3, \mathrm{Q} 0$ & 31 & 16.3 & $\mathrm{~A}^{*} 4=0.1702$ \\
\hline & 3,3 & 27 & 15.9 & $\mathrm{~A}^{*} \mathrm{Q} 0=0.1525$ \\
\hline & 4,3 & 15 & 8.9 & $\mathrm{~A}^{*} 2=0.0461$ \\
\hline & $4, \mathrm{QO}$ & 12 & 7.1 & Others $=0.0213$ \\
\hline & 3,2 & 8 & 4.7 & \\
\hline & 4 & 8 & 4.7 & \\
\hline & 4,4 & 4 & 2.4 & \\
\hline & 4,1 & 3 & 1.8 & \\
\hline & $3,3+2$ & 3 & 1.8 & \\
\hline & 3.1 & 1 & 0.6 & \\
\hline & 2,91 & 1 & 0.6 & \\
\hline & 4,91 & 1 & 0.6 & \\
\hline & $3,3+3$ & 1 & 0.6 & \\
\hline & \multirow[t]{2}{*}{$4,3+2$} & 1 & 0.6 & \\
\hline & & 169 & 100.0 & \\
\hline \multirow[t]{14}{*}{$\mathrm{C} 4 \mathrm{~B}$} & 1 & 50 & 29.6 & $\mathrm{~B}^{* 1} 1=0.6406$ \\
\hline & 2,1 & 49 & 28.9 & $B * 2=0.2740$ \\
\hline & 1,1 & 32 & 18.9 & $B^{*} 5=0.0569$ \\
\hline & 2,2 & 10 & 5.9 & $\mathrm{~B}^{*} \mathrm{Q} 0=0.0178$ \\
\hline & 5,1 & 9 & 5.3 & Others $=0.0107$ \\
\hline & 2 & 4 & 2.4 & \\
\hline & 5 & 4 & 2.4 & \\
\hline & $1, \mathrm{QO}$ & 4 & 2.4 & \\
\hline & 5,2 & 3 & 1.8 & \\
\hline & 4,1 & 1 & 0.6 & \\
\hline & $2, \mathrm{Q} 0$ & 1 & 0.6 & \\
\hline & 13,13 & 1 & 0.6 & \\
\hline & $1,1+1$ & 1 & 0.6 & \\
\hline & & 169 & 100.0 & \\
\hline
\end{tabular}

of $\mathrm{C} 4$ phenotypes in Koreans is similar to that found in Japanese and Chinese. The $\mathrm{C} 4 \mathrm{~A} * 3$ and $\mathrm{C} 4 \mathrm{~B} * 1$ are the most common alleles at each locus in various populations, as was also found in this study. $\mathrm{C} 4 \mathrm{~A}^{*} 6$ is a relatively common allele in Caucasoid and Negroid populations, which is not found in the Korean, Japanese, and Chinese. The $\mathrm{C} 4 \mathrm{~B} * 5$ is a common allele in Asians, which is rare in Caucasoids and Negroids. The $\mathrm{C}_{4} \mathrm{~B}^{* 5}$ appears to be a characteristic allele of the Orientals. 
Table 2. Distribution of $\mathrm{C} 4 \mathrm{~A}$ and $\mathrm{C} 4 \mathrm{~B}$ allele frequencies in various populations.

\begin{tabular}{|c|c|c|c|c|c|c|c|c|c|c|}
\hline \multicolumn{2}{|c|}{$\begin{array}{l}\text { Population } \\
\text { Al lele }\end{array}$} & \multirow{2}{*}{$\begin{array}{c}\begin{array}{c}\text { Korean } \\
(\mathrm{n}=169)\end{array} \\
0.153\end{array}$} & \multirow{2}{*}{$\begin{array}{l}\begin{array}{c}\text { Korean } \\
(\mathrm{n}=99)\end{array} \\
0.079\end{array}$} & \multirow{2}{*}{$\begin{array}{c}\begin{array}{c}\text { Japanese } \\
(\mathrm{n}=341)\end{array} \\
0.067\end{array}$} & \multirow{2}{*}{$\begin{array}{l}\begin{array}{l}\text { Southern } \\
\text { Chinese } \\
(\mathrm{n}=61)\end{array} \\
0.115\end{array}$} & \multirow{2}{*}{$\begin{array}{l}\begin{array}{l}\text { American } \\
\text { Caucasian } \\
(\mathrm{n}=623)\end{array} \\
0.190\end{array}$} & \multirow{2}{*}{$\frac{\begin{array}{c}\text { American } \\
\text { Caucasian } \\
(\mathrm{n}=63)\end{array}}{0.095}$} & \multirow{2}{*}{$\begin{array}{l}\begin{array}{c}\text { American } \\
\text { Black } \\
(n=35)\end{array} \\
0.071\end{array}$} & \multirow{2}{*}{$\begin{array}{l}\begin{array}{c}\text { Finn } \\
(n=254)\end{array} \\
0.113\end{array}$} & \multirow{2}{*}{$\begin{array}{r}\begin{array}{r}\text { Tunisian } \\
(\mathrm{n}=169)\end{array} \\
0.089\end{array}$} \\
\hline$C 4 A^{*}$ & פO & & & & & & & & & \\
\hline & 1 & 0.014 & & & & 0.010 & & 0.057 & & 0.053 \\
\hline & 2 & 0.046 & & 0.106 & 0.041 & 0.055 & 0.016 & 0.042 & 0.081 & 0.124 \\
\hline & 3 & 0.610 & 0.734 & 0.686 & 0.605 & 0.631 & 0.722 & 0.742 & 0.754 & 0.716 \\
\hline & 4 & 0.170 & 0.222 & 0.132 & 0.199 & 0.075 & 0.071 & 0.014 & 0.007 & \\
\hline & 5 & & 0.005 & & & 0.002 & & & & \\
\hline & 6 & & & & & 0.035 & 0.079 & $0.05 ?$ & 0.016 & 0.015 \\
\hline \multicolumn{2}{|c|}{ Dthers } & 0.007 & 0.015 & 0.009 & & 0.002 & 0.008 & 0.014 & & \\
\hline \multirow[t]{7}{*}{$\mathrm{C}_{4} \mathrm{~B}^{*}$} & $\infty$ & 0.018 & 0.155 & 0.158 & 0.147 & 0.104 & 0.111 & 0.071 & 0.175 & 0.003 \\
\hline & 1 & 0.640 & 0.526 & 0.587 & 0.423 & 0.743 & 0.760 & 0.714 & 0.657 & 0.124 \\
\hline & 2 & 0.274 & 0.300 & 0.167 & 0.405 & 0.199 & 0.087 & 0.142 & 0.153 & 0.766 \\
\hline & 3 & & 0.005 & & & 0.021 & 0.024 & 0.071 & 0.016 & 0.098 \\
\hline & 4 & 0.004 & & & & 0.004 & & & & \\
\hline & 5 & 0.057 & & 0.088 & 0.016 & 0.005 & & & & \\
\hline & S & & 0.052 & & & & 0.008 & & & \\
\hline \multicolumn{2}{|c|}{ Others } & 0.007 & 0.015 & & 0.008 & 0.004 & 0.008 & & & 0.012 \\
\hline \multicolumn{2}{|c|}{ Investigators } & $\begin{array}{l}\text { Present } \\
\text { study }\end{array}$ & $\begin{array}{l}\text { Kim } \\
\text { et al., } \\
1986\end{array}$ & $\begin{array}{c}\text { Tokunaga } \\
\text { et al., } \\
1985\end{array}$ & $\begin{array}{l}\text { Hawkins } \\
\text { et al., } \\
1988\end{array}$ & $\begin{array}{l}\text { Alper } \\
\text { et al., } \\
1983\end{array}$ & $\begin{array}{l}\text { Howard } \\
\text { et al., } \\
1986\end{array}$ & $\begin{array}{l}\text { Howard } \\
\text { et al., } \\
1986\end{array}$ & $\begin{array}{l}\text { Partanen } \\
\text { Koskimies, } \\
1986\end{array}$ & $\begin{array}{l}\text { Ayed \& } \\
\text { Gorgli, } \\
1990\end{array}$ \\
\hline
\end{tabular}

Null alleles of $\mathrm{C} 4 \mathrm{~A}$ or $\mathrm{C} 4 \mathrm{~B}$ occurs at frequencies of $0.003-0.190$ in various normal populations. Braun et al. (1990) reported that some of the C4A null alleles were associated with deletion of genes and others were due to nonexpressed genes. Schneider et al. (1986) suggested that gene deletion of C4 loci was associated with deletions of 21-OHA and 21-OHB genes. But, Yamada et al. (1990) reported that the deletion of C4A gene was not found in Japanese patients with SLE $(0 \%)$, or in healthy controls $(0.6 \%)$.

Six different rare $\mathrm{C} 4$ phenotypes with duplicated form were detected. Raum et al. (1984) and Giles et al. (1987) found a duplication of the C4A locus on the haplotype C4A 3 C4A 2 C4B Q0. The present study shows that duplication of one $\mathrm{C} 4$ locus is accompanied with the null allele of the other $\mathrm{C} 4$ locus in three individuals (one with C4A $3,3+2 \mathrm{C} 4 \mathrm{~B}$ 1, Q0, one with $\mathrm{C} 4 \mathrm{~A} \quad 4,3+3 \mathrm{C} 4 \mathrm{~B}$ 2,Q0, and one with $\mathrm{C} 4 \mathrm{~A} 3$, Q0 $\mathrm{C} 4 \mathrm{~B} 1,1+1$ ). This result suggests that a $\mathrm{C} 4 \mathrm{~A}$ gene has been 
converted to a $\mathrm{C} 4 \mathrm{~B}$ gene, and reverse. $\mathrm{Yu}$ and Campbell (1987) reported that the C4B locus of the HLA haplotype B44 DRw6 C4A 3 C4B Q0 was not actually a $\mathrm{C} 4 \mathrm{~B}$ null allele, but probably had been encoded by another C4A 3 allotype. Also, Partanen and Campbell (1989) and Tokunaga et al. (1991) showed that the both C4B loci of C4A $3+2$ C4B Q0 and C4A 3+3 C4B Q0 haplotypes where duplicated form of $\mathrm{C} 4 \mathrm{~A}$ allele and $\mathrm{C} 4 \mathrm{~B}$ null allele correspond to $\mathrm{C} 4 \mathrm{~A}$ gene instead of $\mathrm{C} 4 \mathrm{~B}$ gene.

$\mathrm{C} 4$ variants and null alleles of this study were based on electrophoretic mobility of the $\mathrm{C} 4$ protein. This data did not include the analysis on the DNA level for the observed null alleles and duplicated variants. Recently, restriction fragment length polymorphism (RFLP) has been proved to be useful in the investigation of the basis of C4 genetic variants including the null alleles (Mimori et al., 1990; Braun et al., 1990; Schneider, 1990).

Acknowledgment This study was supported by the grant from the Korea Science and Engineering Foundation, KOSEF 911-0406-093-1.

\section{REFERENCES}

Alper CA, Raum D, Karp S, Awdeh ZL, Yunis EJ (1983): Serum complement 'Supergenes' of the major histocompatibility complex in man (complotypes). Vox Sang 45: 62-67

Awdeh ZL, Alper CA (1980): Inherited structural polymorphism of the fourth component of human complement. Proc Natl Acad Sci USA 77: 3576-3580

Ayed K, Gorgi Y (1990): C3, BF and C4 polymorphisms in Tunisians. Hum Hered 40: 363-367

Braun L, Schneider PM, Giles CM, Bertrams J, Ritter C (1990): Null alleles of human complement $\mathrm{C} 4$ : Evidence for pseudogenes at the $\mathrm{C} 4 \mathrm{~A}$ locus and for gene conversion at the $\mathrm{C} 4 \mathrm{~B}$ locus. J Exp Med 171: 129-140

Carroll MC, Campbell RD, Bentley DR, Porter RR (1984): A molecular map of the human major histocompatibility complex class III region linking complement genes $\mathrm{C} 4, \mathrm{C} 2$ and factor $\mathrm{B}$. Nature 307: 237-241

Carroll MC, Belt KT, Palsdottir A, Yu Y (1985): Molecular genetics of the fourth component of human complement and steroid 21-hydroxylase. Immunol Rev 87: 39-60

Chiarelli F, Verrotti A, Penna GL, Morgese G (1988): Low serum C4 concentration in type-I diabetes mellitus. Eur J Pediatr 147: 197-198

Dunham I, Sargent CA, Trowsdale J, Campbell RD (1987): Molecular mapping of the human major histocompatibility complex by pulsed-field gel electrophoresis. Proc Natl Acad Sci USA 84: $7237-7241$

Giles CM (1990): C4: Rodgers and Chido typing. Complement Inflamm 7: 213-217

Giles CM, Uring-Lambert B, Boksch W, Braun M, Goetz J, Neumann R, Mauff G, Hauptmann G (1987): The study of a French family with two duplicated C4A haplotypes. Hum Genet 77: $359-365$

Hawkins BR, Serjeantson SW, Higgins DA (1988): Distribution and co-occurrence of MHC class I, II and III markers in Southern Chinese: Implications for autoimmune disease. Dis Markers 6: $237-245$

Howard PF, Hochberg MC, Bias WB, Arnett FC, McLean RH (1986): Relationship between C4 null genes, HLA-D region antigens, and genetic susceptibility to systemic lupus erythematosus in Caucasian and Black Americans. Am J Med 81 : 187-193 
Kim SJ, Nisperos B, Mickelson E, Choi IH, Dahlberg S, Kim JD, Giblett ER, Hansen JA (1986): The HLA system in the Korean population. Human Immunol 17: 259-272

Mauff G, Alper CA, Awedh Z, Batchetor JR, Bertrams J, Brunn-Petersen, G Dawkins RL, Demant P, Edwards J, Grosse-Wilde H, Hauptmann G, Klouda P, Lamm L, Mollenhauer E, Nerl C, Olaisen B, O'Neill G, Rittner C, Roos MH, Skanes V, Teisberg P, Wells L (1983): Statement on the nomenclature of human $C 4$ allotypes. Immunobiology 164: 184-191

Mauff G, Bender K, Giles CM, Goldmann S, Opferkuch W, Wachauf B (1984): Human C4 polymorphism: Pedigree analysis of qualitative, quantitative, and functional parameters as a basis for phenotype interpretations. Hum Genet 65: 362-372

Mauff G, Alper CA, Dawkins R, Doxiadis G, Giles CM, Hauptmann G, Rittner C, Schneider PM (1990): C4 Nomenclature Statement (1990). Complement Inflamm 7: 261-268

Mimori A, Takeuchi F, Tokunaga K, Maeda H, Matsuki K, Matsuta K, Nakano K, Kosuge E, Yukiyama Y, Omoto K, Miyamoto T (1990): Restriction fragment length polymorphism of complement $\mathrm{C} 4$ in Japanese patients with rheumatoid arthritis and normal Japanese. Tissue Antigens 35: 197-202

O'Neill GJ, Yang SY, Dupont B (1978): Two HLA-linked loci controlling the fourth component of human complement. Proc Natl Acad Sci USA 75: 5165-5169

Partanen J, Campbell RD (1989): Restriction fragment analysis of non-deleted complement C4 null genes suggests point mutations in C4A null alleles, but gene conversions in $\mathrm{C} 4 \mathrm{~B}$ null alleles. Immunogenetics 30: 520-523

Partanen J, Koskimies S (1986): Human MHC class III genes, Bf and C4. Polymorphism, complotypes and association with MHC class I genes in the Finnish population. Hum Hered 36: $269-275$

Porter RR (1985): The complement components coded in the major histocompatibility complexes and their biological activities. Immunol Rev 87: 7-17

Raum D, Awdeh Z, Anderson J, Strong L, Granados J, Teran L, Giblett E, Yunis EJ, Alper CA (1984): Human C4 haplotypes with duplicated C4A or C4B. Am J Hum Genet 36: 72-79

Rosenfeld SI, Ruddy S, Austen KF (1969): Structural polymorphism of the fourth component of human complement. J Clin Invest 48: 2283-2292

Schneider PM, Carroll MC, Alper CA, Rittner C, Whitehead AS, Yunis EJ, Colten HR (1986): Polymorphism of the human complement $\mathrm{C} 4$ and steroid 21-hydroxylase genes: Restriction fragment length polymorphisms revealing structural deletions, homoduplications, and size variants. J Clin Invest 78: 650-657

Schneider PM (1990): C4 DNA RFLP reference typing report. Complement Inflamm 7: 218-224

Schreiber RD, Müller-Eberhard HJ (1974): Fourth component of human complement: Description of a three polypeptide chain structure. J Exp Med 140: 1324-1335

Spence MA, Spurr NK, Field LL (1989): Report of the committee on the genetic constitution of chromosome 6. Cytogenet Cell Genet 51: 149-165

Tack BF, Janatova J, Thomas ML, Harrison RA, Hammer CH (1981): The third, fourth, and fifth components of human complement: Isolation and biochemical properties. Methods Enzymol 80: 64-101

Tokunaga K, Omoto K, Akaza T, Akiyama N, Amemiya H, Naito S, Sasazuki T, Satoh H, Juji $\mathrm{T}$ (1985): Haplotype study on C4 polymorphism in Japanese. Association with MHC alleles, complotypes, and HLA-complement haplotypes. Immunogenetics 22: 359-365

Tokunaga K, Zhang WJ, Christiansen FT, Dawkins RL (1991): The genomic structure of two ancestral haplotypes carrying C4A duplications. Immunogenetics 34: 247-251

Vergani D (1987): Complement in type I (insulin-dependent) diabetes. Diabetologia 30: 823

Yamada H, Watanabe A, Mimori A, Nakano K, Takeuchi F, Matsuta K, Tanimoto K, Miyamoto T, Yukiyama Y, Tokunaga K, Yokohari R (1990): Lack of gene deletion for complement in Japanese patients with systemic lupus erythematosus. J Rheumatol 17: 1054-1057 
Yu CY, Campbell RD (1987): Definitive RFLPs to distinguish between the human complement C4A/C4B isotypes and the major Rodgers/Chido determinants: Application to thestudy of C4 null alleles. Immunogenetics 25: 383-390

Yu CY, Campbell RD, Porter RR (1988): A structural model for the location of the Rodgers and the Chido antigenic determinants and their correlation with the human complement component C4A/C4B isotypes. Immunogenetics 27: 399-405

Yu CY (1991): The complete exon-intron structure of a human complement component C4A gene: DNA sequences, polymorphism and linkage to the 21-hydroxylase gene. J Immunol 146: 10571066 